\title{
Evaluation of the Sustainability of Tourism in Ihlara Valley and Suggestions
}

\author{
By Dr. Funda Varnacı Uzun ${ }^{1}$, Dr. Mehmet Somuncu ${ }^{2}$
}

\begin{abstract}
Study area of the present study, Ihlara Valley is located within the borders of Cappadocia region in central Anatolia. With its physical structure and cultural landscape, Ihlara Valley is an important international tourist destination. In addition to this, the area is under national protection as a specially protected environment area. Churches carved on the rock walls of Ihlara Valley, caves and frescos are some of the cultural landscape values in the region. In the present study, the purpose is to evaluate the sustainability of tourism activities in Ihlara Valley and to develop suggestions for the area to have sustainable tourism. Whether the tourism activities in Ihlara Valley are sustainable or not was evaluated based on the sustainable tourism criteria proposed by Gebhard et al. (2008). These four main criteria include 18 sub-criteria and in the present study, 11 of these criteria were found to have low values, 6 of them have medium values and only 1 of them has a high value and particularly the values found for the sub-criteria involved in the main criterion of management and monitoring are low, which shows that the tourism activities in the region are not sustainable. In the second part of the study, suggestions were developed for tourism to be sustainable in Ihlara Valley by evaluating the protection status of the cultural landscape that is one of the important components of sustainable tourism, tourist satisfaction and development of the local community through analytic hierarchy process method.
\end{abstract}

Keywords: Sustainable tourism, protection of cultural landscape, sustainable economic development, sustainable tourist satisfaction, local people, analytic hierarchy process

\section{Introduction}

With its potential to develop, tourism can be defined as the main drive of the world economy as the second biggest industry after petroleum industry in the world and this makes tourism an important part of sustainable development (Fennell, 2003; Hunt, 2009).

The sustainable tourism approach was started to be popularly used with the adaptation of Brundtland Report into the sector by academicians and tourism professionals (Hall and Lew, 1998). When the sustainable tourism is regarded as the adaptation of the concept of sustainability into tourism in compliance with Brundtland Report, it can be defined as "as a type of tourism meeting the needs of tourists and local people without preventing the satisfaction of the needs of the future generations" (Swarbrooke, 1999). But, the most widely used short definition of the sustainable tourism is proposed by The World Tourism Organization (WTO, 2010); "The sustainable tourism means development and protection of the opportunities for the future while meeting the needs of today's tourists and host regions."

The sustainable tourism approach can be explained on the basis of three components: Economic, social and environmental (Butler, 2000). From economic point of view, sustainability can be summarized as the minimization of the harms and costs stemming from tourism and optimization of the benefits of it; equal sharing of the benefits of the tourism among the individuals of societies particularly having low socio-economic status and supporting of the local economies in

2 Prof. Dr., Ankara University, Faculty of Languages, History and Geography, Department of Geography, AnkaraTurkey. 
the local community (Butler, 1999). Environmental sustainability requires the protection of the environment not only for the sustainability of tourism but also for the maintenance of the life (Hall and Lew, 1998). Socio-cultural sustainability in general is related to the local population that is viewed to be culture manufacturer of the society (Pineda and Brebbia, 2004).

Though there are various studies conducted to evaluate the sustainability of tourism in a specific area, there are no universally agreed criteria to be used to evaluate the sustainability. Gebhard et al., (2008) used community well-being, protection of the natural and cultural environment, product quality and tourist satisfaction and management and monitoring as the criteria to evaluate the sustainability of tourism in an area (Somuncu and Yiğit, 2009). If these criteria are met or satisfied for an area, then the tourism in the area is considered to be sustainable (Gebhard et al., 2008; Somuncu and Yiğit, 2009). The characteristics of the criteria used to evaluate sustainability are also explained as follows (Gebhard et al., 2008; Somuncu ve Yiğit, 2009):

Community well-being: Development of sustainable tourism supports the economic, social and cultural development of the local people. The sub-criteria of this main criterion include some processes ranging from the development of income level to the development of local traditions.

Protection of the natural and cultural environment: While sustainable tourism allows the exploitation of the natural and cultural resources for economic benefits, it ensures the protection of these resources at the same time.

Product quality and tourist satisfaction: The quality of the product offered in a tourist area is a key factor for the success of tourism economy. The evaluation of this quality should not be based on only the evaluation of the quality of concrete criteria such as transportation, accommodation and food and beverage but also on the evaluation of abstract criteria such as hospitality of local people and the quality of tourist experiences.

Management and monitoring: For the above mentioned three criteria to be met in an area, management and monitoring criterion is required. Though it may be assumed that sustainable tourism can be achieved without a management and monitoring system, it is impossible in practice. Therefore, the management and monitoring system is responsible for the fulfillment of the other criteria. Thus, this criterion must be taken into consideration in the evaluation of the others

\section{Materials and Methods}

\subsection{Study area}

The study area of the current research is Ihlara Valley, which is an important international tourist destination situated within the borders of Cappadocia Region in Central Anatolia. The most important tourist attraction of Ihlara Valley is its geomorphologic structure coming into being as a result of a process having been lasting for thousands of years. The volcanic area created by the volcanic activities of Hasan Mountain and Melendiz Mountain was used as a religious center for hundreds of years. Churches carved on the rock walls of Ihlara Valley, caves and frescos are some of the cultural values in the region and they are another important tourist attraction. The number of visitors visiting the area in 2013 is 344,418 .

\subsection{Evaluation based on the sustainable tourism criteria}

In the current study, to determine whether the area is sustainable or not, the sustainable tourism criteria proposed by Gebhard et al., (2008) were used. In this regard, the evaluation of the area was conducted on the basis of four main criteria; community well-being, protection of the natural and cultural environment, product quality and tourist satisfaction and management and monitoring, and their 18 sub-criteria.

In the evaluation of the community well-being criterion, the data collected through the interviews 
conducted with 44 people were used. In order to evaluate the criterion of the protection of the natural and cultural environment, the protection and exploitation of landscape values were analyzed by means of the observation technique. In the evaluation of the protect quality criterion, the data collected through questionnaires administered to 583 tourists visiting the area were used. And in the evaluation of the management and monitoring criterion, the data collected through the interviews conducted with local governors were used. In light of the findings, the criteria were evaluated as low, medium and high and then they were interpreted.

\subsection{Development of suggestions via analytic hierarchy process (AHP)}

In the current study, analytic hierarchy process was conducted to determine the shortmid- and long-term suggestions for the tourism activities carried out in Ihlara Valley to accomplish the main target of sustainable tourism. The components of sustainable tourism were determined to be sub-targets. Thus, sub-targets for AHP were set to be Protection of the Cultural Landscape, Tourist Satisfaction and Local Development.

In line with these sub-targets, three factors were determined as cultural landscape values, tourist expectations and local people's expectations. The sub-factors of each factor were constructed based on the results of observations, interviews and surveys conducted in the area.

The factors and sub-factors were ordered from top to bottom in a hierarchy for 3 alternatives. Within the framework of the established hierarchy, matrices were constructed for comparisons. For the determination of significance of binary values, the opinions of 7 experts were sought in a special meeting. During the evaluation conducted by the experts, measurement scale developed by Saaty (1990) was employed. The arithmetic means of the scores given by the experts during the evaluation were taken as the basis of the analysis.

\section{Results}

\subsection{Evaluation based on the sustainable tourism criteria}

As a result of the evaluation of the sustainability of the tourism activities conducted in Ihlara Valley according to the sustainable tourism criteria proposed by Gebhard et al., (2008), the following findings were obtained.

\subsubsection{Evaluation of the community well-being criterion:}

The main income source of the local people living in Ihlara Valley is agriculture. While $77 \%$ of the population in Güzelyurt province including Ihlara Valley area is recruited in agriculture sector, only $21 \%$ of the local people work in service sectors including tourism. This shows that income taken from the tourism activities by the local people is low.

Table 1. Evaluation of the community well-being criterion

\begin{tabular}{|l|c|c|c|}
\hline Criteria & High & Medium & Low \\
\hline Income and revenues & & & $\mathbf{X}$ \\
\hline Employment & & & $\mathbf{X}$ \\
\hline Strengthening of the local economy and of long-term economic viability & & & $\mathbf{X}$ \\
\hline Improvement of living conditions & & $\mathbf{X}$ & \\
\hline Participation \& local control & & & $\mathbf{X}$ \\
\hline Satisfaction with tourism & & $\mathbf{X}$ & \\
\hline Strengthening of social and cultural patterns & & $\mathbf{X}$ & \\
\hline
\end{tabular}

In addition to this, during the interviews, the local people stated that tourists visit the region but they do not have any gains from these visits and this indicates that the local people do not get much from tourism activities. The number of the families getting some income from tourism is 
quite small. The organizations offering services to tourists in the region are limited to 7 organizations serving food and beverages and 5 pensions. In light of these findings, among the community well-being criteria, "incomes and revenues", "employment" and "strengthening of the local economy and of long-term economic viability" criteria are evaluated as low (Table 1).

The local governors stated that infrastructure has been developed for them to have better conditions. Renovation of the roads for tourists and other infrastructure works also improved the living conditions of the local people. However, as the entrance fees are not yet allocated to infrastructure works, their effects cannot be felt by the local people. As a result, "improvement of living conditions" criterion is evaluated to be medium (Table 1). Lack of a tourism planning for the region and the local governors' failure to develop a plan to involve all the stakeholders in tourism activities show that "participation and local control" criterion is low (Table 1).

During the interviews with the local people, it was observed that the local people have positive attitudes towards the development of tourism and strong beliefs that the tourism could contribute to the development of the local society. However, some of the local people are against the tourism activities as they think that these activities are not suitable for the traditional structure of the local people and these activities result in environmental pollution. As there are two different general attitudes to tourism activities, "satisfaction with tourism" and "strengthening of social and cultural patterns" criteria are evaluated to be medium (Table 1).

\subsubsection{Evaluation of the natural and cultural values criterion:}

Only 12 of the many churches and caves carved in rock in Ihlara Valley were approved to be $1^{\text {st }}$ degree archeological sites by The Konya Board of the Protection of the Cultural Values. Ihlara Valley itself is under the protection as a specially protected area. Despite this protection status, there are many problems experienced in the protection of the cultural landscape values.

None of the frescos inside the registered churches have been protected well and they have been destructed by both the local people and tourists. When it comes to non-registered structures, some of the structures carved on the wall of the valley cannot be reached due to rockslides. Some of the churches whose structures have been well protected are used by the local people as warehouses to store their grains.

Though the old houses located in the research area are under protection, many of them are in disrepair and cannot be used. Moreover, none of the underground caves found in the research are exploited for tourism purposes. These caves are used to damp garbage and as barns and animal houses.

Table 2. Evaluation of the natural and cultural values criterion

\begin{tabular}{|l|c|c|c|}
\hline Criteria & High & Medium & Low \\
\hline Sustainable use of natural and cultural resources & & & $\mathbf{X}$ \\
\hline Protection of natural heritage & & & $\mathbf{X}$ \\
\hline Protection of cultural heritage & & & $\mathbf{X}$ \\
\hline Enhancement of environmental awareness & & $\mathbf{X}$ & \\
\hline
\end{tabular}

As stated by the local governors, the Ministry does not provide funds for protection, renovation and maintenance attempts in the area and most of the renovation projects are conducted with the initiative of the local governors and this shows that funds spared for protection are limited.

In light of this information, it can be argued that protection and sustainable use of the cultural landscape values is quite problematic. Therefore, of the natural and cultural environment protection criteria, "sustainable use of the natural and cultural resources", "protection of the natural heritage" and "protection of the cultural heritage" criteria are evaluated to be low. During the interviews, the local people stated that the rock churches must be protected for tourism purposes. Thus, "enhancement of environmental awareness" criterion is evaluated to be medium (Table 2). 


\subsubsection{Evaluation of product quality and tourist satisfaction criteria:}

Natural structure and cultural landscape of Ihlara Valley are important tourist attractions. However, more than this is needed for attracting tourists here such as transportation and accommodation facilities. The questionnaires administered to tourists revealed that the tourists' satisfaction with the infrastructure in the area is low. Moreover, the tourists' perceptions of tourist services are also quite bad.

No precautions have been taken to prevent rockslides to the areas where tourists reside and this is a clear indication of the safety problems in the area. Furthermore, there are not suitable conditions for the disabled and elderly to visit the valley. Thus, "quality of services and experience" criterion is evaluated to be low (Table 3).

Table 3. Evaluation of product quality and tourist satisfaction criteria

\begin{tabular}{|l|c|c|c|}
\hline Criteria & High & Medium & Low \\
\hline Quality of services and experience & & & X \\
\hline Tourist satisfaction & & $\mathbf{X}$ & \\
\hline Tourism product quality and economic viability & & & $\mathbf{X}$ \\
\hline Communication of sustainability to the tourists & & $\mathbf{X}$ & \\
\hline Cultural exchange as a driving force for peace & $\mathbf{X}$ & & \\
\hline
\end{tabular}

The results of the questionnaire administered to tourists visiting Ihlara Valley revealed that while their level of satisfaction with the cultural landscape values in the area is high, their level of satisfaction with the infrastructure facilities in the area is low. This shows that the expectations of the tourists are met at a medium level. In addition to this, for $80 \%$ of the visitors, this is their first visit. The ratio of revisiting the area is about $20 \%$. Thus, "tourist satisfaction" can be evaluated to be medium (Table 3).

There is no study having investigated the product quality in Ihlara Valley. The total number of tourists visiting the area since 2007 has been experiencing steady increase. However, as their stay in the area is limited to few hours and they do not reside in the area, their spending in the area is low. Thus, "tourism product quality and economic viability" criterion is evaluated to be low (Table 3).

In the evaluation of the use of the tourism activities in the area according to the criterion of capitalizing on cultural change for peace, local people's attitudes towards tourists and the tourists' attitudes towards the local people are analyzed. The interviews conducted with the local people revealed that high majority of the local people have positive attitudes towards the development of tourism activities in the area and they do not have conflicts with tourists. The results of the questionnaire administered to the tourists showed that the tourists have quiet positive attitudes towards the participation of the local people in tourism and their becoming local guides. Thus, "cultural exchange as a driving force for peace" criterion is evaluated to be high. (Table 3).

\subsubsection{Evaluation of management and monitoring criterion:}

There is no planning and monitoring activity for the management of Ihlara Valley for sustainable tourism purposes. During the interviews conducted with the local governors, it was detected that there is an attempt in this direction. Moreover, lack of coordination and authority conflicts between the interested institutions in the area make planning more difficult. In addition to lack of planning, there is also no information center to inform visitors about the area. Furthermore, fundamental facilities such as WC, car park and food and beverage organizations are not enough in the area.

There is no capacity evaluation conducted for the area. Especially in May and June, the area is used very intensely and there is no system to regulate the use in this high season. This makes the protection of the cultural landscape values in the valley more difficult and leads to increasing destruction. Thus, "planning and management" and "carrying capacity" criteria are evaluated to be low. 
(Table 4).

Table 4. Evaluation of management and monitoring criterion

\begin{tabular}{|l|c|c|c|}
\hline Criteria & High & Medium & Low \\
\hline Planning and management & & & $\mathbf{X}$ \\
\hline Carrying capacity & & & $\mathbf{X}$ \\
\hline
\end{tabular}

\subsection{Development of Suggestions via Analytic Hierarchy Process (AHP)}

In the determination of the alternatives to be attached priority in the short-, mid- and long-term plans of sustainable tourism activities to be conducted in Ihlara Valley, first three factors being the cultural landscape values, tourist expectations and the expectations of the local people were compared.

As a result of the comparison of these basic factors, it was found that the most important factor is the cultural landscape values with 0.73064 and it is followed by tourist expectations with 0.18839 and the expectations of the local people with 0.08096 .

\section{Matrix: Basic Factors}

\begin{tabular}{l|c|c|c|c} 
& $\begin{array}{c}\text { Cultural } \\
\text { Landscape Values }\end{array}$ & $\begin{array}{c}\text { Tourist } \\
\text { Expectations }\end{array}$ & $\begin{array}{c}\text { Local People } \\
\text { Expectations }\end{array}$ & $\begin{array}{c}\mu_{\text {Basic }} \\
\text { Factors }\end{array}$ \\
\hline Cultural Landscape Values & 1 & 5 & 7 & 0.73064 \\
\hline Tourist Expectations & & 1 & 3 & 0.18839 \\
\hline Local People Expectations & & & 1 & 0.08096 \\
\hline
\end{tabular}

$\mathrm{U}_{\max } 3.06489 \quad$ Consistency Index (CI): 0.03244 Consistency Ratio (CR): 0.05594

Thus, it is clear that the factor of the cultural landscape values is the most influential factor on the alternative factors in tourism activities to be proposed for Ihlara Valley.

\subsubsection{Comparison of the Cultural Landscape Values Factors}

The comparison revealed that the most important sub-factor here is rock churches and cathedrals with 0.50153 it is followed by frescos with 0.24805 and then by the old houses with 0.13855 .

\begin{tabular}{l|l|l|l|c|c|c} 
Matrix: Cultural Landscape Values Factors & $\begin{array}{l}\text { Rock churches } \\
\text { and cathedrals }\end{array}$ & Frescos & $\begin{array}{c}\text { Underground } \\
\text { caves }\end{array}$ & $\begin{array}{c}\text { Old } \\
\text { houses }\end{array}$ & $\begin{array}{c}\text { Other cultural } \\
\text { landscape values }\end{array}$ & $\begin{array}{l}\mu \text { Cultural } \\
\text { landscape }\end{array}$ \\
\hline Rock churches and cathedrals & 1 & 3 & 5 & 5 & 9 & 0.50153 \\
\hline Frescos & & 1 & 3 & 3 & 7 & 0.24805 \\
\hline Underground caves & & & 1 & $1 / 3$ & 3 & 0.07782 \\
\hline Old houses & & & & 1 & 5 & 0.13855 \\
\hline Other cultural landscape values & & & & & 1 & 0.03406 \\
\hline
\end{tabular}

$\mathrm{U}_{\max } 5.25193 \quad$ CI: $0.06298 \quad$ CR: 0.05623

\subsubsection{Comparison of Tourist Expectations Factors}

The companion showed that the most important sub-factor here is tourism marketing and services with the value of 0.42357 . 
Matrix: Tourist Expectations Factors

\begin{tabular}{|c|c|c|c|c|c|c|}
\hline & $\begin{array}{l}\text { Tourist } \\
\text { equipments } \\
\text { and } \\
\text { information }\end{array}$ & $\begin{array}{l}\text { Tourist } \\
\text { marketing } \\
\text { and } \\
\text { services }\end{array}$ & $\begin{array}{l}\text { Protection of } \\
\text { the cultural } \\
\text { and natural } \\
\text { values }\end{array}$ & $\begin{array}{c}\text { Participation } \\
\text { of the local } \\
\text { people in } \\
\text { tourism }\end{array}$ & $\begin{array}{l}\text { Use of the old } \\
\text { houses for } \\
\text { tourism } \\
\text { purposes }\end{array}$ & $\begin{array}{c}\mu \text { Tourist } \\
\text { Expectations }\end{array}$ \\
\hline $\begin{array}{l}\text { Tourist equipments and } \\
\text { information }\end{array}$ & 1 & $1 / 2$ & 1 & 3 & 6 & 0.23173 \\
\hline $\begin{array}{l}\text { Tourist marketing and } \\
\text { services }\end{array}$ & & 1 & 3 & 5 & 5 & 0.42357 \\
\hline $\begin{array}{l}\text { Protection of the cultural } \\
\text { and natural values }\end{array}$ & & & 1 & 3 & 5 & 0.20908 \\
\hline $\begin{array}{l}\text { Participation of the local } \\
\text { people in tourism }\end{array}$ & & & & 1 & 3 & 0.08898 \\
\hline $\begin{array}{l}\text { Use of the old houses for } \\
\text { tourism purposes }\end{array}$ & & & & & 1 & 0.04665 \\
\hline
\end{tabular}

$\breve{U}_{\max } 5.17604$ CI: $0.04401 \quad$ CR: 0.03930

It is followed by tourist equipments and information with 0.23173 and protection of the cultural and natural values with 0.20908 . Participation of the local people in tourism (0.08898) and the use of the old houses for tourism purposes $(0.04665)$ were found to be the least important ones.

\subsubsection{Comparison of the Local People's Expectations Factors}

As a result of this comparison, the most important sub-factor was found to be job opportunities connected with tourism with the value of 0.56519 . It is followed by education for tourism purposes sub-factor with 0.22961 and by the protection of the cultural landscape values sub-factor with 0.10735 and then by approval for the repair-renovation of the old houses with 0.09786 .

\section{Matrix: Local People's Expectations Factors}

\begin{tabular}{|c|c|c|c|c|c|}
\hline & $\begin{array}{c}\text { Job opportunities } \\
\text { connected with } \\
\text { tourism }\end{array}$ & $\begin{array}{l}\text { Education } \\
\text { for tourism }\end{array}$ & $\begin{array}{l}\text { Protection of the } \\
\text { cultural landscape } \\
\text { values }\end{array}$ & $\begin{array}{l}\text { Approval for the } \\
\text { repair-renovation } \\
\text { of the old houses }\end{array}$ & $\begin{array}{c}\mu_{\text {Local }} \\
\text { People's } \\
\text { Expectations } \\
\end{array}$ \\
\hline $\begin{array}{l}\text { Job opportunities } \\
\text { connected with tourism }\end{array}$ & 1 & 3 & 5 & 5 & 0.56519 \\
\hline Education for tourism & & 1 & 2 & 3 & 0.22961 \\
\hline $\begin{array}{l}\text { Protection of the cultural } \\
\text { landscape values }\end{array}$ & & & 1 & 1 & 0.10735 \\
\hline $\begin{array}{l}\text { Approval for the repair- } \\
\text { renovation of the old } \\
\text { houses }\end{array}$ & & & & 1 & 0.09786 \\
\hline
\end{tabular}

$\breve{U}_{\max } 4.03414 \quad$ CI: $\quad 0.01138 \quad$ CR: 0.01264

\subsubsection{Evaluation of the alternative on the basis of all the factors}

As a result of the comparison of all the factors with each other and their evaluation based on the alternatives, the best short-term alternative for the sustainable tourism activities in Ihlara Valley was determined to be the protection of the cultural landscape values in Ihlara Valley with the value of 0.59967 .

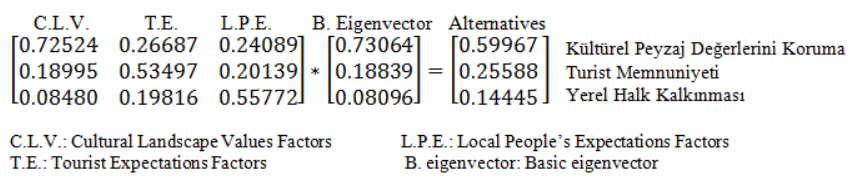


As the best mid-term alternative, tourist satisfaction with 0.25588 was determined. An as the best long-term alternative, development of the local community with 0.14445 was found.

\section{Conclusion and Suggestions}

As a result of the evaluation of the tourism activities in Ihlara Valley based on the sustainable tourism criteria proposed by Gebhard et al., (2008), it was found that 11 criteria of the 18 sub-criteria making up four main criteria are low, 6 of them are medium and 1 of them is high; thus, it was concluded that the tourism activities are not sustainable here.

The following suggestions were developed as a result of the analytic hierarchy process conducted to develop suggestions and determine the priority of these suggestions to make tourism activities in Ihlara Valley sustainable:

\subsection{Short-term suggestions:}

$\checkmark$ Effective protection of the cultural landscape values in the area.

$\checkmark$ Making the specially protected area status more effective and then trying to obtain an international protection status for the area.

$\checkmark$ Protection and maintenance efforts directed towards the churches, cathedral and frescoes in the area should be given the highest priority. The registered churches should be cleaned and the damaged frescoes should be renovated. The surroundings of the churches should be cleaned.

$\checkmark$ Information boards that are in compliance with the natural environment should be placed around the churches. Moreover, path ways and stages used to get to the churches should be repaired. Direction boards placed to help tourists to find their ways should be prepared in different languages and their sizes should be standardized. Necessary precautions must be taken to prevent rockslides and warning signs should be placed.

$\checkmark$ The non-registered churches must be handled. These churches must be registered and applications conducted on the registered churches should also be carried out for these churches.

$\checkmark$ The old houses should be restored in compliance with their traditional forms.

$\checkmark$ The under-ground caves should be located and cleaned.

$\checkmark$ For the activities to be conducted to protect the cultural landscape values and for the continuation of this protection, some of the revenues gained from Ihlara Valley and Selime Cathedral should be spared for the protection and maintenance of these values.

\subsection{Mid-term suggestions:}

The main target in mid-term is to enhance tourist satisfaction for the sustainability of tourism activities in Ihlara Valley. For this purpose, following suggestions can be made:

$\checkmark$ Hospitality organizations with high service quality should be opened to accommodate tourists visiting Ihlara Valley and its surroundings. These organizations should be established through the restoration of old houses or the construction of new buildings in the original architecture of the region. Moreover, the number of food and beverage organizations in the area need to be increased and their quality must be enhanced.

$\checkmark$ An internet site should be designed to promote and market the area.

$\checkmark$ Another thing that should be done to increase tourist satisfaction is related to tourist equipments and information. At the entrance of the valley, a tourist information center must be set up.

$\checkmark$ While descending into the valley, the stairs must be used but they are in disrepair; thus, they should be repaired and maintained. Hand-rails must be renewed. Moreover, some seats should be placed at certain places for people to sit while climbing or descending the stairs. The toilets should be rebuilt and must always be kept clean. The number of benches, dust bins and lamps in 
the valley must be increased.

$\checkmark$ Observation terraces should be built at points having good view of the valley. The present observation terraces need maintenance and cleaning.

Through such activities, tourist satisfaction and the time they spend in the area is expected to increase. This will naturally contribute to long-term attempts.

\subsection{Long-term suggestions:}

The main long-term target for the sustainability of the tourism activities in Ihlara Valley is the development of the local community. Some of the suggestions to be made for this purpose also help to meet tourist expectations. The suggestions to be made for this purpose are as follows: $\checkmark$ The local people should be encouraged to participate in tourism activities. As such, job opportunities connected with tourism should be increased.

$\checkmark$ The hospitality organizations and food and beverage organizations planned to increase tourist satisfaction should be opened and managed by local people. Local people, particularly women, should be encouraged to produce handcrafts to sell. Volunteer local people should be trained to be tourist guides in the region.

$\checkmark$ The local people should be educated through various panels and seminars so that they can understand how to participate in tourism activities and to protect the cultural landscape values. Moreover, handcarts and foreign language courses should be opened for the local people.

$\checkmark$ The local people should be encouraged to participate in restoration works in the area. And local people should be encouraged to manage the restored old houses as pensions.

Finally, a tourism management plan must be developed for the realization of the suggestions given above for Ihlara Valley.

\section{References}

Fennell, D., (2003), Ecotourism, London: Routledge.

Hunt, C. A., (2009), We Are Even Poorer, But There is More Work: An Ethnographic Analysis of Ecotourism in Nicaragua, PhD Thesis, USA: Texas A\&M University.

Hall, C.M., Lew, A.A., (1998), Sustainable Tourism: A Geographical Perspective, USA: Longman.

Swarbrooke, J., (1999), Sustainable Tourism Management, UK: CABI Publishing.

WTO, (2010), (http://www.world-tourism.org/sustainable/doc/a21-def.pdf, 20.02.2010)

Butler, R., (1999), "Sustainable Tourism: A State of the Art Review", Tourism Geographies, V.1, pp.7-25.

Butler, R., (2000), "Tourism and the environment: a geographical perspective", Tourism Geographies, V.2, N.3, pp.337-358.

Pineda, E.D., Brebbia, C.A.(ed)., (2004), Sustainable Tourism, Boston: WITPress.

Gebhard, K., Meyer, M., Roth, S., (2008), Criteria for Sustainable Tourism for the three Biosphere Reserves: Aggtelek, Babia Góra and Šumava. Ecological Tourism in Europe and UNESCO MaB.

Somuncu, M., Yiğit, T., (2009), “Göreme Milli Parkı Ve Kapadokya Kayalık Sitleri Dünya Mirası Alanı'ndaki Turizmin Sürdürülebilirlik Perspektifinden Değerlendirilmesi”, Ankara: V. Ulusal Coğrafya Sempozyumu, 16-17 Ekim 2008, Bildiriler Kitabı, pp.387-402,

Saaty, T.L., (1990), "How to make a decision: The Analytic Hierarchy Process", European Journal of Operational Research, V.48, pp.9-26. 
